\title{
Rancang Bangun Game Aksi dengan Integrasi dan Pengenalan Gambar Menggunakan Algoritma Ekstraksi Fitur SURF dan Klasifikasi SVM pada Perangkat Android
}

\author{
Bryan Nandriawan, Imam Kuswardayan, Nanik Suciati \\ Jurusan Teknik Informatika, Fakultas Teknologi Informasi, Institut Teknologi Sepuluh Nopember (ITS) \\ Jl. Arief Rahman Hakim, Surabaya 60111 Indonesia \\ e-mail:imam@its-sby.edu
}

\begin{abstract}
Abstrak-Saat ini perangkat mobile berbasis Android dan iOS sangat digemari oleh anak-anak. Mereka yang telah memiliki perangkat mobile akan menghabiskan seluruh waktunya untuk menatap layar perangkat saat bermain. Akibat yang ditimbulkan adalah penurunan kesehatan mata dan kurangnya bersosialisasi dengan teman sebaya. Menggambar adalah hal yang disukai anak-anak. Dengan menggabungkan menggambar dengan permainan perangkat mobile, anak-anak akan tetap merasa bermain meski mereka sedang tidak menatap layar untuk menggambar. Tugas akhir ini bertujuan untuk membangun sebuah permainan yang dapat mengenali gambar dan menggunakan gambar tersebut dalam permainan. Metode pengenalan gambar dalam tugas akhir ini dilakukan dengan menggunakan metode Edge Detection dengan algoritma ekstraksi fitur SURF (Speeded-Up Robust Features) dan klasifikasi SVM (Support Vector Machine). Jenis permainan yang dibangun merupakan gabungan dari aksi dan tower defense. Hasil dari tugas akhir ini dibagi menjadi 3 yaitu hasil fungsionalitas permainan, hasil daya tarik permainan dan hasil akurasi pengenalan gambar. Semua fungsi yang dibuat pada permainan dapat berjalan dengan baik, dan permainan juga telah memiliki daya tarik yang memikat. Namun hasil akurasi pengenalan gambar masih kurang dari harapan penulis.
\end{abstract}

Kata Kunci-Android, Klasifikasi Gambar, Permainan, SURF, SVM

\section{PENDAHULUAN}

$\mathrm{P}$ ERANGKAT mobile berbasis Android dan iOS sangat digemari di masyarakat. Kemajuan teknologi yang sangat cepat dalam bidang ini, membuat banyak kebiasaan dan budaya masyarakat berubah. Seperti budaya anak-anak yang biasa bermain di luar rumah bersama teman, kini telah digantikan dengan bermain gadget sendirian. Banyaknya aplikasi, permainan dan hiburan yang ditawarkan dalam sebuah gadget, seringkali membuat pengguna menatap layar secara berlebihan. Perilaku ini seringkali ditiru oleh anak-anak yang juga tertarik pada perangkat pintar ini. Anak-anak generasi muda saat ini sudah sangat mengenal perangkat ini, bahkan tidak sedikit yang lebih mahir menggunakannya dibanding orang tua mereka. Namun anak-anak tidak bisa mengatur waktu mereka ketika mereka bermain. Mereka akan menghabiskan seluruh waktunya untuk menatap layar perangkat saat bermain, ketika tidak ada pengawasan dari orang tua. Hal ini tentu berbahaya bagi kesehatan mata dan kebiasaan bersosialisasi mereka. Karena itu, seharusnya setiap permainan memiliki sistem atau fitur untuk menghentikan pemain dalam bermain terlalu lama.

Untuk mengatasi persoalan tersebut, diperlukan permainan yang dapat menghentikan pemain secara langsung ataupun secara tidak langsung dalam menatap layar, namun pemain akan tetap merasa bermain dalam permainan tersebut. Dengan menugaskan pemain untuk menggambar suatu benda terlebih dahulu untuk dapat digunakan dalam permainan, akan membuatnya secara tidak langsung berhenti menatap layar perangkat. Pemain akan menggambar di kertas sesuai dengan objek yang diminta lalu gambar tersebut difoto dan dikenali. Gambar yang telah dikenali selanjutnya diubah menjadi objek di dalam permainan dan dapat digunakan. Tujuan dari pengenalan gambar adalah mencegah pemain berbuat curang dengan menggambar sesuatu yang tidak ditugaskan.

Dalam tugas akhir ini, pengenalan gambar menggunakan metode Edge Detection dengan algoritma ekstraksi fitur SURF (Speeded-Up Robust Features), Bag of Words dan klasifikasi SVM (Support Vector Machine) yang diharapkan dapat mengenali berbagai variasi (skala, rotasi dan bentuk) suatu jenis objek, sehingga tidak membatasi kreatifitas pemain. Pembentukan training model dengan ekstraksi fitur menggunakan algoritma SURF, Bag of Words dan klasifikasi menggunakan SVM pada beberapa jenis objek yang telah dipilih akan dilakukan terlebih dahulu. Lalu model akan dibandingkan dengan fitur dari gambar yang baru dibuat oleh pemain dengan mencari jarak terdekat. Level yang dibuat bertingkat dalam permainan diharapkan dapat mengasah kemampuan pemain dalam menggambar. Keseluruhan permainan ini tentunya akan membuat pemain merasa tetap bermain saat mereka beristirahat dari menatap layar perangkat.

Tujuan dari pembuatan tugas akhir ini adalah membuat permainan yang dapat membuat pemain berhenti menatap layar untuk menggambar sebuah benda yang kemudian difoto dan dikenali sebagai benda yang diminta. 


\section{TINJAUAN PUSTAKA}

\section{A. Game Aksi dan Tower Defense}

Game aksi adalah salah satu Genre permainan yang seringkali membutuhkan refleks, kecepatan tangan, timing, dan koordinasi mata dengan tangan. Sedangkan Tower Defense adalah genre permainan yang memaksa pemain untuk bertahan dari serangan musuh yang berdatangan. Beberapa game mobile tidak hanya menyenangkan, namun juga edukatif. Sisi edukatif ini dikembangkan untuk membuat pemain menggunakan waktu bermainnya untuk sesuatu yang bermanfaat juga [1].

\section{B. OpenCV untuk Android}

OpenCV (Open Source Computer Vision) adalah sebuah pustaka perangkat lunak yang ditujukan untuk pengolahan citra dinamis. Pustaka OpenCV mendukung penggunaan pada Android Development. Dengan menggunakan fungsi-fungsi yang ada dalam OpenCV, akan memudahkan pembuatan aplikasi yang membutuhkan visi komputer. Digunakan asset Unity dengan nama "OpenCv for Unity" untuk thresholding gambar dari kamera dan resize untuk memperkecil ukuran gambar.

\section{SURF, Bag of Words dan Klasifikasi SVM}

SURF: "Speeded up Robust Features" adalah salah satu algoritma pencarian ujung ("Edge Detection"). SURF adalah versi lebih cepat dari SIFT (Scale-Invariant Feature Transform). SURF dipilih karena sifatnya yang robust dalam mendeteksi fitur, dan karena tidak dibutuhkan perhitungan secara real-time dalam kasus ini. SURF juga dipilih karena memiliki descriptor dengan 64 nilai poin ambang yang lebih ringkas namun memiliki semua informasi penting, daripada SIFT yang memiliki descriptor dengan 128 nilai poin ambang. Pada MATLAB algoritma SURF yang digunakan telah ada dalam kelas Bag of Words [2].

Bag of Words (BoW) dalam visi komputer adalah penyerderhanaan dalam representasi fitur sebuah gambar dalam kata-kata. Pembentukan BoW akan melewati 3 tahap yaitu deteksi fitur, deskripsi fitur dan pembuatan codebook. Setelah dilakukan deteksi fitur dan deskripsi fitur, akan dihasilkan descriptors berupa vector. Terakhir, dengan melakukan $K$ Means Clustering pada semua vector, vector akan diubah ke bentuk codewords dalam codebooks. Codebooks berupa kumpulan histogram vector [3].

Support Vector Machine (SVM) adalah suatu teknik untuk melakukan prediksi, baik dalam kasus klasifikasi maupun regresi. SVM berada dalam satu kelas dengan Artificial Neural Network (ANN) dalam hal fungsi dan kondisi permasalahan yang bisa diselesaikan. Keduanya masuk dalam kelas supervised learning. Pemilihan SVM dalam kasus ini karena SVM efektif dalam multidimensional spaces [4].

\section{MATLAB Compiler SDK}

MATLAB compiler SDK adalah salah satu fitur dari MATLAB dimana sourcecode MATLAB yang telah dibuat dapat diubah menjadi $\mathrm{C} / \mathrm{C}++$ shared libraries, Microsoft .NET assemblies, Java class, dan Python packages. Kemudian komponen baru tersebut dapat diintegrasikan dengan aplikasi yang dapat di deploy di desktop, web, dan sistem enterprise.

\section{E. Game Design}

Game Design merupakan unsur-unsur yang ada dalam pembuatan sebuah permainan. Perancangan game design yang baik akan menghasilkan game yang baik pula. Game design dapat dibagi menjadi 2 yaitu Game Mechanics dan Game Dynamics. Game Mechanics adalah suatu desain metode atau aturan yang dibuat untuk pemain berinteraksi. Metode dan aturan ini dibuat dengan tujuan agar pemain merasa cukup tertantang dan terhibur dalam memainkan suatu game. Game Dynamics atau yang sering disebut gameplay adalah tujuan yang diberikan kepada pemain untuk dapat menyelesaikan game atau level yang ada [5].

\section{ANALISIS DAN PERANCANGAN}

\section{A. Analisis Permainan}

Permainan ini dibangun dengan tujuan untuk membantu pemain mengistirahatkan matanya dari layar, namun tetap memberikan kondisi berada dalam permainan. Permainan ini mengharuskan pemain menggambar objek yang dibutuhkan dalam permainan dengan gambar tangan pada kertas. Gambar kemudian difoto untuk kemudian dikenali dengan tujuan apakah objek tersebut sesuai dengan yang sedang diminta. Aplikasi ini dibangun untuk perangkat mobile dengan aplikasi Unity. Pengenalan gambar dilakukan terpisah dengan menggunakan halaman web lokal dan mengirimkan gambar untuk dikenali. Halaman web lokal dibuat dengan ASP .Net pada Microsoft Visual Studio dan telah tertanam .Net assembly dari MATLAB sebagai dasar algoritma pengenalan.

\section{B. Perancangan Game Mechanics Game Dynamics dan Peraturan Permainan}

Game mechanics yang ada dalam permainan ini adalah:

1. Sistem pergantian peralatan. Sebelum memulai permainan, pemain dapat memilih peralatan yang pemain miliki untuk dibawa, sehingga memungkinkan pemain berganti senjata di dalam pertandingan.

2. Sistem pembatas serangan. Pemain dalam pertandingan akan menggunakan peralatan untuk dapat menyerang musuh, namun setiap serangan yang dilakukan akan berharga sejumlah mana atau stamina. Mana dan stamina memiliki jumlah maksimum dan minimum dan pengurangannya tergantung dari jenis senjata yang digunakan. Jika mana atau stamina habis, maka pemain harus mengisinya dengan menekan tombol untuk mengisi mana atau stamina.

3. Sistem multi-touch. Pemain dapat mengisi mana atau stamina bersamaan dengan menyerang musuh.

4. Tingkat kesulitan bertahap. Tingkat kesulitan tiap level tidaklah random namun meningkat bertahap. Setiap pemain akan mendapatkan musuh yang sama pada level yang sama.

5. Sistem RPG (Role Playing Games). Sistem ini lebih spesifik kepada pemain yang dapat mendapatkan gold atau mata uang yang ada dalam permainan. Pemain mendapatkan gold setiap level terselesaikan. Gold dapat digunakan untuk meningkatkan kekuatan karakter pemain dan peralatannya. Game dynamics pada permainan ini adalah:

1. Mengalahkan semua musuh yang datang, sebelum jumlah HP (Hit Points) pemain mencapai 0. 
2. Mendapatkan gold untuk mempermudah permainan di level berikutnya.

3. Membuka peralatan baru dengan melakukan pengenalan gambar.

Peraturan permainan yang dibuat adalah:

1. Tujuan setiap level adalah mengalahkan semua musuh yang ada

2. Tidak ada batasan waktu dalam satu level permainan, namun saat musuh habis permainan akan berakhir

3. Pemain memiliki Hit Point (HP) yang akan berkurang bila terkena serangan, dan permainan akan berakhir bila Hit Point pemain mencapai 0.

4. Pemain memiliki mana dan stamina yang berkurang bila pemain menyerang musuh. Mana dan stamina yang habis bisa diisi lagi dengan menekan tombol mana dan stamina.

5. Setiap musuh akan bergerak mendekat lalu menyerang pemain.

6. Pemain akan menang apabila semua musuh telah terkalahkan, dan level berikutnya akan terbuka.

\section{Perancangan Sistem}

Sistem yang dibangun pada Android adalah permainan yang berdasarkan game mechanics dan dynamics seperti yang telah disebutkan dan pengenalan gambar. Sistem pengenalan yang ada pada bagian Android adalah pengambilan gambar baru menggunakan kamera, penyesuaian thresholding gambar sesuai keinginan pemain dengan $O p e n \mathrm{Cv}$, dan pengiriman gambar ke halaman web lokal dengan metode POST, dan menerima respon dari halaman web lokal.

Berdasarkan uraian permainan dan pengenalan gambar yang telah dijelaskan sebelumnya, terdapat beberapa spesifikasi kebutuhan fungsionalitas permainan yang harus dibuat, seperti pada Gambar 1.

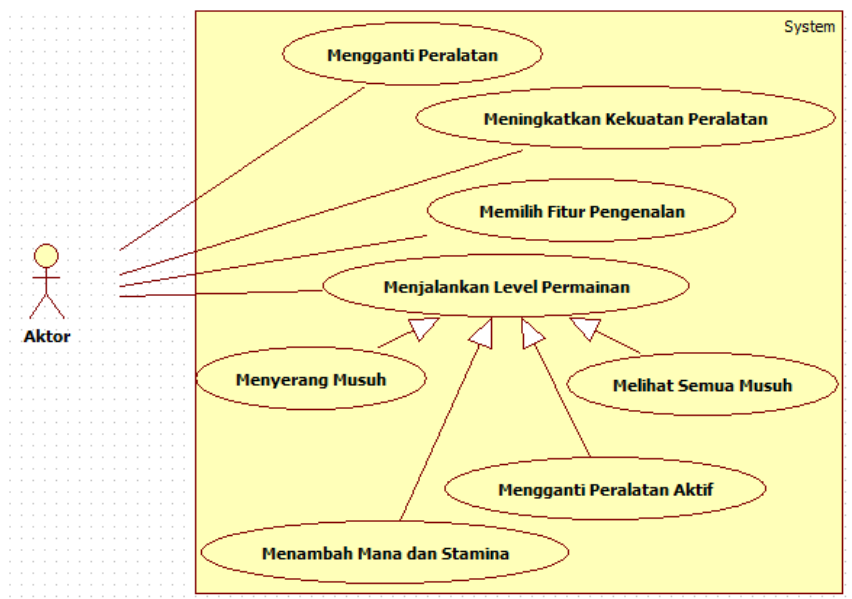

Gambar 1 Diagram Use Case

\section{Perancangan Dataset untuk Pengenalan}

Dataset yang dibuat meliputi kategori peralatan yang akan dikenali, yaitu pedang, tongkat sihir, kapak, tombak, bom, dan pisau. Semua dataset gambar diambil dari search engine Google sebanyak 100 pada tiap kategori. Pada mulanya, ukuran tiap-tiap gambar diubah menjadi 480 x 270 pixels. Gambar kemudian dibuat hitam putih dan background dibersihkan sehingga menjadi putih. Contoh masing-masing dataset dapat dilihat pada Gambar 2, masing-masing baris adalah satu kategori. Baris pertama adalah pedang, kemudian tongkat sihir, kapak, tombak, bom dan terakhir pisau.

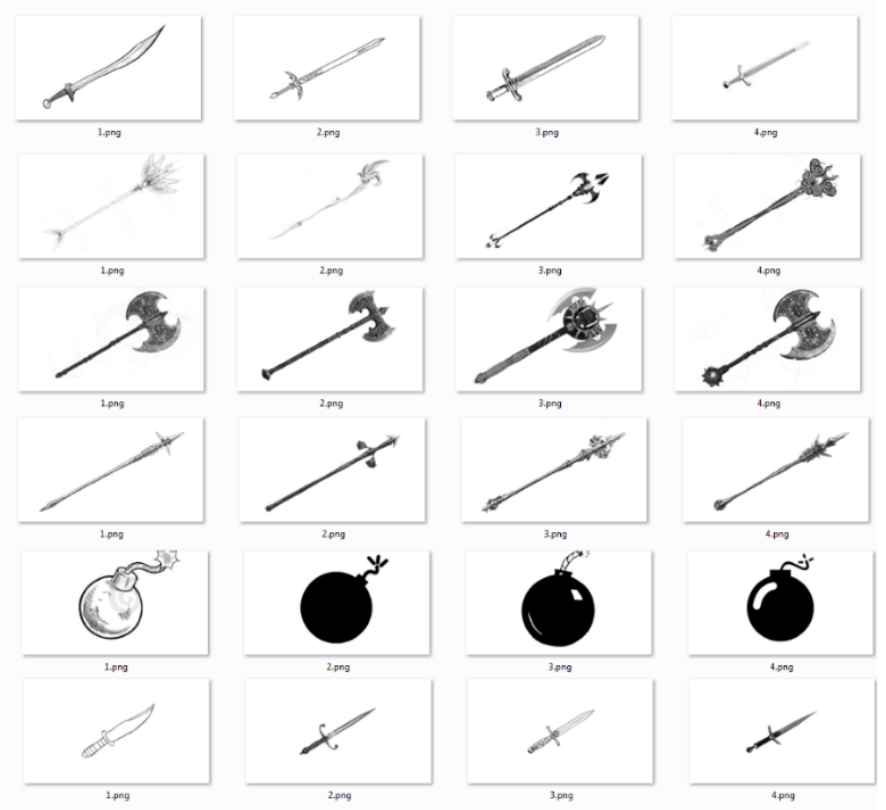

Gambar 2. Contoh 6 kategori dataset

\section{E. Perancangan Pengenalan}

Sistem pengenalan yang dibuat melalui 4 tahap yaitu pembuatan dataset, pembuatan model klasifikasi dengan MATLAB, pembuatan prediksi pengenalan data baru dengan MATLAB, dan mengubah kode prediksi pengenalan data baru menjadi .Net assembly.

Pembuatan model klasifikasi dilakukan dengan fungsi-fungsi MATLAB. Awalnya semua 6 kategori dataset diekstraksi fiturnya menggunakan SURF. Kemudian Fitur tersebut diseleksi menggunakan Bag of Words. Fitur-fitur yang terpilih kemudian di klasifikasi menggunakan SVM. Hasil pada workspace MATLAB kemudian disimpan sebagai model klasifikasi.

Setelah model klasifikasi dibentuk, model dapat dimuat pada workspace baru. Kemudian data gambar baru dapat dimuat dan diprediksi dengan menggunakan fungsi dari MATLAB. Fungsi-fungsi ini dituliskan dalam bentuk kode.

Kode yang bertugas memprediksi data baru dapat diubah menjadi .Net assembly menggunakan fitur aplikasi library compiler pada MATLAB. Hasil dari aplikasi ini adalah sebuah library dengan ekstensi ".dll.".

\section{F. Perancangan Halaman Web}

Perancangan halaman Web menggunakan ASP .Net dengan bahasa C\#. Halaman web dibangun dengan hanya dapat menerima metode POST. Halaman web menggunakan library tambahan yang berasal dari MATLAB. Halaman web menerima 3 jenis masukan yang kemudian di proses pada 3 bagian yang dijelaskan secara singkat sebagai berikut:

1. Pembuatan user baru ditujukan untuk membuat folder pada direktori lokal dengan nama user tersebut. Sistem menerima angka random sebagai username, lalu sistem mengecek apakah angka tersebut sudah ada dalam direktori lokal. Bila 
belum ada maka sistem akan menyimpan angka sebagai username dengan membuat folder baru. Bila sudah ada sistem akan mengirim response untuk memilih ulang angka random.

2. Penyimpanan gambar ditujukan untuk menyimpan gambar pada direktori lokal. Sistem menerima username sebagai penentu letak folder yang akan diisi gambar.

3. Deteksi gambar ditujukan untuk mengenali gambar yang telah disimpan dalam direktori lokal. Sistem memproses gambar dengan memanggil fungsi dari library tambahan. Sistem kemudian mengirimkan response berisi hasil deteksi gambar.

\section{IMPLEMENTASI}

Permainan dibuat menggunakan bahasa $\mathrm{C \#}$ dengan aplikasi Unity 5.2.1fl. Fitur-fitur utama yang diimplementasikan dalam permainan adalah penyimpanan data, pergantian peralatan, pertandingan dalam sebuah level, pengambilan gambar dan pengiriman gambar.

Penyimpanan data adalah pembuatan file berisi data progress permainan pemain. Penyimpanan dan pemuatan data dilakukan secara otomatis.

Fitur pergantian peralatan berfungsi untuk mengganti peralatan yang akan dibawa pemain di dalam pertandingan. Peralatan yang dibawa dapat ditingkatkan kekuatannya dengan fitur tambahan yaitu meningkatkan kekuatan peralatan. Peralatan yang akan dibawa beserta tingkat kekuatannya disimpan dalam penyimpanan lokal.

Fitur pertandingan dalam sebuah level membutuhkan fitur pemilihan level. Fitur pemilihan level bertugas untuk memberikan tingkat kesulitan bertahap pada pemain. Fitur pertandingan merupakan fitur paling kompleks dalam permainan ini. Di dalamnya dibutuhkan banyak fitur yang bekerja bersamaan. Fitur-fitur tersebut adalah: Fitur serangan jarak jauh dan serangan jarak dekat, fitur pergerakan musuh dan serangan musuh, fitur mana dan stamina, fitur mengganti peralatan aktif, dan fitur melihat semua musuh. Implementasi pertandingan dapat dilihat pada Gambar 3.

Fitur pengambilan gambar berfungsi untuk mengaktifkan kamera perangkat dan menunjukkannya pada layar. Dengan menekan sebuah tombol, maka gambar akan disimpan di penyimpanan lokal. Gambar yang telah disimpan kemudian diproses dengan fitur tambahan yaitu Thresholding sebelum gambar dikirim. Proses thresholding dapat dikontrol oleh pengguna untuk menghilangkan background sesuai kebutuhan. Implementasi thresholding dapat dilihat pada Gambar 4.

Fitur pengiriman gambar berfungsi untuk mengirimkan gambar ke halaman web. Sistem melakukan koneksi dengan halaman web sebanyak 3 kali, yang pertama untuk membuat user baru, yang kedua untuk mengirim gambar, dan yang terakhir untuk mengirim perintah deteksi gambar. Halaman web akan memberikan respon yang kemudian diolah oleh sistem.

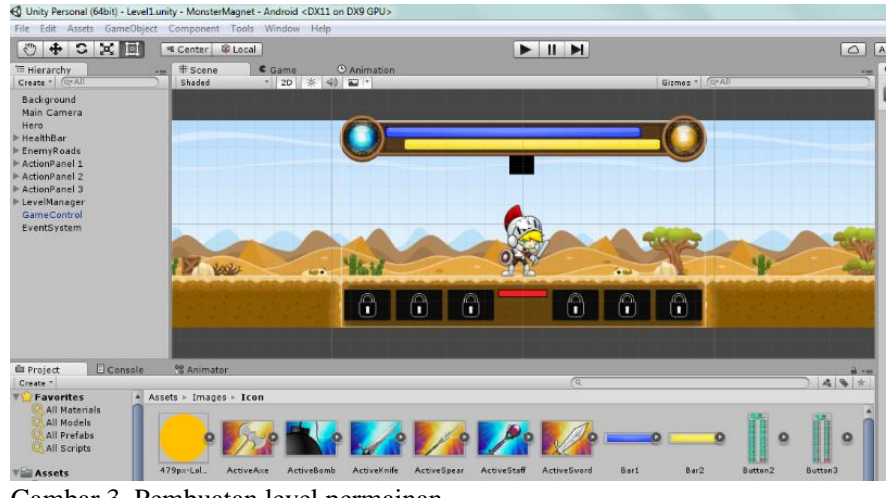

Gambar 3. Pembuatan level permainan

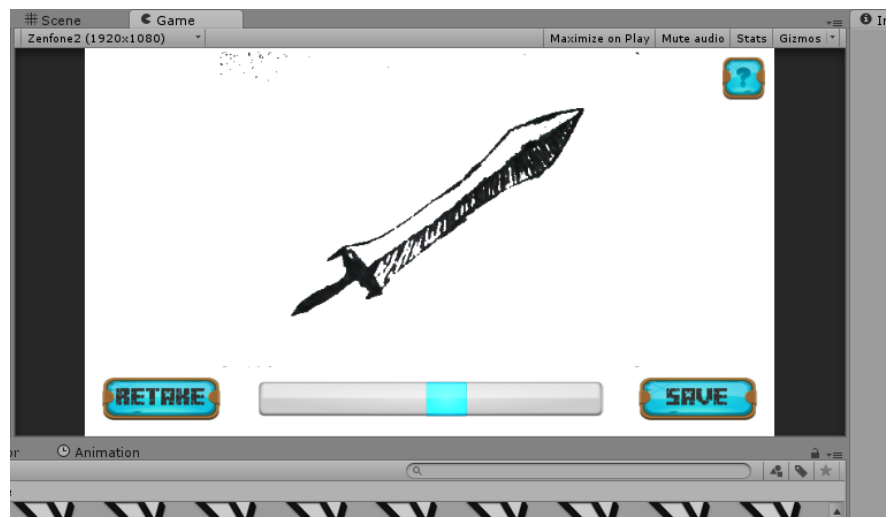

Gambar 4. Tampilan proses thresholding

Pengenalan gambar dibuat dengan fungsi-fungsi dan aplikasi library compiler pada MATLAB. Fungsi pertama adalah fungsi penyimpanan workspace berisi model klasifikasi. Fungsi kedua adalah fungsi prediksi data baru dengan model klasifikasi sebelumnya. Fungsi kedua yang berupa kumpulan kode kemudian dibuat menjadi .Net assembly dengan aplikasi MATLAB.

Pembuatan halaman web dilakukan dengan memproses 3 jenis input yaitu pembuatan user, penyimpanan gambar dan deteksi gambar. Halaman web menggunakan IIS x64(Internet Information Services) dan "Debug x64" dan tambahan referensi dari library MATLAB.

\section{PENGUJIAN DAN EVALUASI}

Pengujian fungsionalitas dilakukan dengan menyiapkan sejumlah skenario sebagai tolok ukur keberhasilan pengujian. Pengujian fungsionalitas dengan mengacu pada kasus penggunaan dari aplikasi yang dikembangkan. Hasil pengujian fungsionalitas menunjukkan semua skenario pengujian berhasil dan program berjalan dengan baik. Sehingga bisa disimpulkan bahwa fungsionalitas dari program telah bisa bekerja sesuai dengan yang diharapkan. Hasil pengujian fungsionalitas dapat dilihat pada Tabel 1. Hasil uji coba integrasi gambar dapat dilihat pada Gambar 5. 
Tabel 1.

Pengujian Fungsionalitas

\begin{tabular}{llll}
\hline \hline ID & Deskripsi & & Hasil \\
\hline & & Skenario 1 & Berhasil \\
UJ-UC-001 & Uji Coba Pengenalan & Skenario 2 & Berhasil \\
& Gambar & Skenario 3 & Berhasil \\
& & Skenario 4 & Berhasil \\
& Uji Coba Integrasi & Skenario 5 & Berhasil \\
UJ-UC-002 & Gambar pada Objek & Skenario 1 & Berhasil \\
& Game & Skenario 1 & Berhasil \\
& & Skenario 2 & Berhasil \\
& & Skenario 3 & Berhasil \\
UJ-UC-003 & Uji Coba Aturan Main & Skenario 4 & Berhasil \\
& & Skenario 5 & Berhasil \\
& & Skenario 6 & Berhasil \\
& & Skenario 1 & Berhasil \\
UJ-UC-004 & Uji Coba Skenario & Skenario 2 & Berhasil \\
\hline \hline & Permainan & & \\
\hline
\end{tabular}

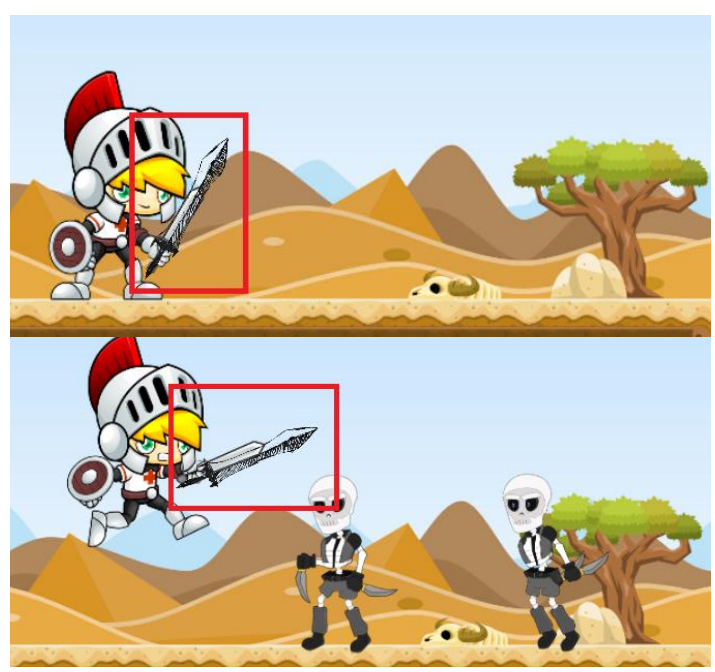

Gambar 5. Uji coba integrasi gambar pada objek game

Pengujian non-fungsionalitas dilakukan dengan menyiapkan sejumlah skenario sebagai tolok ukur keberhasilan pengujian. Pengujian non-fungsionalitas dilakukan untuk mengetahui bagaimana hasil keluaran selain dari sisi fungsionalitas sistem terhadap skenario yang dipersiapkan. Hasil pengujian nonfungsionalitas menunjukkan bahwa permainan cukup menarik dan mudah dimengerti bagi pengguna baru. Hasil pengujian non-fungsionalitas dapat dilihat pada Tabel 2.

Tabel 2.

Pengujian non-fungsionalitas

\begin{tabular}{clc}
\hline \hline ID & Deskripsi & Rata-rata Nilai \\
\hline UJ-UC-005 & $\begin{array}{l}\text { Uji Coba Daya Tarik } \\
\text { UJ-UC-006 }\end{array}$ & $\begin{array}{l}\text { Permainan } \\
\text { Uji Coba Kejelasan } \\
\text { Permainan }\end{array}$ \\
\hline \hline
\end{tabular}

Pengujian akurasi pengenalan gambar dilakukan dengan menyiapkan 10 gambar pada masing- masing kategori peralatan sebagai tolok ukur keberhasilan pengujian. Pengujian akurasi pengenalan gambar dilakukan untuk mengetahui bagaimana tingkat keberhasilan sistem dalam mengenali gambar baru. Hasil pengujian akurasi pengenalan gambar menunjukkan tingkat pengenalan yang cukup rendah, hal ini mungkin disebabkan oleh jumlah dataset yang perlu diperbanyak.
Beberapa gambar yang di uji coba ditunjukkan pada Gambar 6. Hasil pengujian akurasi pengenalan gambar dapat dilihat pada Tabel 3.

Tabel 3 .

Pengujian akurasi pengenalan gambar

\begin{tabular}{clc}
\hline \hline ID & Deskripsi & Rata-rata Nilai \\
\hline UJ-UC-007 & Uji Coba Akurasi & 6.5 \\
& Pengenalan Gambar & \\
\hline \hline
\end{tabular}
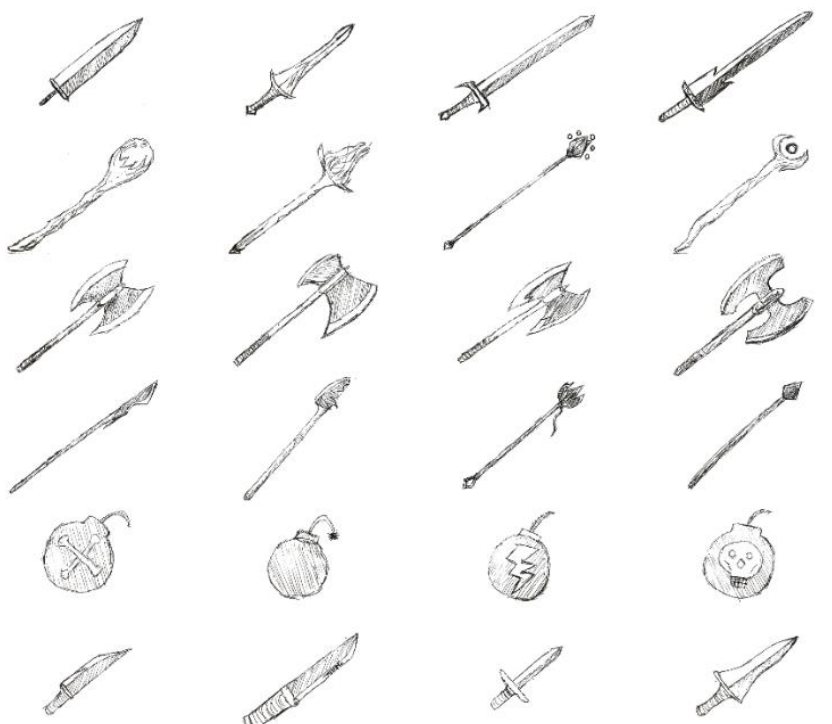

Gambar 6. Sebagian gambar yang dikenali

\section{KESIMPULAN}

Dari hasil uji coba yang telah dilakukan terhadap permainan dan sistem pengenalannya, dapat diambil kesimpulan sebagai berikut:

1. Menurut hasil uji coba kotak hitam terhadap uji coba fungsionalitas, aplikasi ini sudah memenuhi ekspektasi harapan penulis.

2. Menurut hasil uji coba daya tarik permainan, permainan telah memiliki daya tarik yang baik bagi pengguna.

3. Menurut uji coba kejelasan permainan, pengguna baru dapat dengan mudah mengerti alur permainan.

4. Menurut hasil uji coba pengenalan gambar, sistem belum dapat menentukan kategori suatu gambar dengan akurat.

\section{UCAPAN TERIMA KASIH}

Penulis B.N. mengucapkan punji syukur terhadap Allah Subhanahu wa ta'ala yang telah melimpahkan kesehatan, semangat, dan hidayah-Nya sehingga penulis Alhamdulillah mampu menyelesaikan penelitian dengan baik. Penulis juga mengucapkan terima kasih kepada Bapak Imam Kuswardayan dan Ibu Nanik Suciati yang telah banyak membantu penulis dalam menyelesaikan penelitian ini. 


\section{DAFTAR PUSTAKA}

[1] M. Simkova, "Using of Computer Games in Supporting Education," Procedia - Social and Behavioral Sciences, vol. 141, pp. 1224-1227, 2014.

[2] P. Sykora, P. Kamencay and R. Hudec, "Comparison of SIFT and SURF Methods for Use on Hand Gesture Recognition based on Depth Map," AASRI Procedia, vol. 9, pp. 19-24, 2014.

[3] W. Chong and H. Kaiqi, "How to use Bag-of-Words model better for image classification," Image and Vision Computing, vol. 38, pp. 65-74, 2015.

[4] M. Slavomir, H. Robert, K. Patrik, B. Miroslav and Z. Martina, "Classification of Wild Animals based on SVM and Local Descriptors," AASRI Procedia, vol. 9, pp. 25-30, 2014.

[5] T. T. Cota, L. Ishitania and N. Vieira Jr., "Mobile game design for the elderly: A study with focus on the motivation to play," Computers in Human Behavior, vol. 51, pp. 96-105, 2015. 